\title{
PENGARUH BRAND IMAGE, SERVICE QUALITY, DAN CUSTOMER SATISFACTION TERHADAP CUSTOMER LOYALTY SICEPAT DI JABODETABEK
}

\author{
Kristian Irfansius Dan Carunia Mulya Firdausy \\ Program Studi Manajemen/Akuntansi Fakultas Ekonomi Universitas Tarumanagara, Jakarta \\ kristian.115170133@stu.untar.ac.id \\ caruniaf@pps.untar.ac.id
}

\begin{abstract}
The increasing number of online stores in Indonesia makes the use of expedition services more and more. One of these expedition service companies is SiCepat. This study aims to examine whether brand image, service quality, and customer satisfaction have a positive relationship to SiCepat customer loyalty in Jabodetabek. The number of samples used in this study were 100 respondents and used non-probability sampling techniques, especially convenience sampling, where the g-form questionnaire was distributed online through social media. Data analysis was processed using SEM-PLS. The results of this study indicate that brand image has a positive but not significant effect on customer loyalty, while service quality and customer satisfaction have a positive and significant effect on customer loyalty SiCepat in Jabodetabek. Therefore, SiCepat company needs to give serious attention to maintain and improve both service quality and customer satisfaction of the services given to consumers.
\end{abstract}

Keywords: Brand Image, Service Quality, Customer Satisfaction, SiCepat

\begin{abstract}
Abstrak: Meningkatnya toko online di Indonesia membuat penggunaan jasa ekspedisi semakin banyak. Salah satu perusahaan jasa ekspedisi ini adalah SiCepat. Penelitian ini bertujuan untuk menguji apakah brand image, service quality, dan customer satisfaction mempunyai hubungan positif terhadap customer loyalty SiCepat di Jabodetabek. Jumlah sampel yang digunakan dalam penelitian ini yaitu sebanyak 100 responden dan memakai teknik non-probability sampling, khususnya convenience sampling, dimana kuesioner g-form disebarkan secara online melalui media sosial. Analisis data diolah menggunakan SEM-PLS. Hasil penelitian ini menunjukkan bahwa brand image berpengaruh positif tetapi tidak signifkan terhadap customer loyalty, sedangkan service quality dan customer satisfaction berpengaruh positif dan signifikan terhadap customer loyalty SiCepat di Jabodetabek. Oleh karena itu, perusahaan SiCepat perlu memberikan perhatian yang serius untuk menjaga dan meningkatkan baik kualitas pelayanan maupun kepuasan pelanggan atas pelayanan yang diberikan kepada konsumen.
\end{abstract}

Kata Kunci: Citra Merek, Kualitas Layanan, Kepuasan Pelanggan, SiCepat

\section{LATAR BELAKANG}

Jumlah toko online di Indonesia terus meningkat dari tahun ke tahun. Hal itu terjadi karena tren berbelanja online yang telah menjadi kebiasaan. Pertumbuhan toko online yang semakin pesat membuat penggunaan jasa logistik dan ekspedisi juga ikut meningkat. Jasa ekspedisi dan logistik berperan penting dalam mewadahi pengiriman barang secara langsung kepada konsumen dan kemampuannya untuk mengirim barang sampai ke luar daerah.

Survei cepat yang dilakukan MarkPlus, Inc menemukan bahwa 39\% dari 122 responden di Indonesia, menyatakan ada kenaikan penggunaan jasa ekspedisi khusunya pada masa pandemi 
Covid-19 (Kontan.co.id). Salah satu jasa pengiriman yang banyak digunakan pada e-commerce dan marketplace ini adalah SiCepat, yang telah menjadi perusahaan ekspedisi cukup lama di Indonesia sejak tahun 2014 (SiCepat.com). Logo perusahaan SiCepat ini dapat dilihat pada Gambar 1.

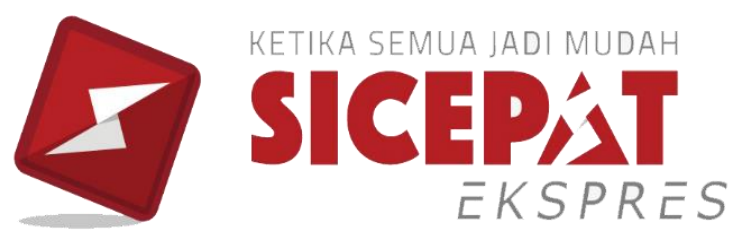

\section{Gambar 1. Logo SiCepat}

Namun, masalah utama pada customer loyalty yang dihadapi SiCepat adalah preferensi dan konsitensi konsumen yang berubah. Perubahan ini terjadi karena adanya brand yang lebih baik dan menguntungkan, contohnya Wahana yang menawarkan ongkos kirim lebih murah. Dengan adanya brand pesaing, konsumen yang memiliki sifat price sensitive akan lebih mudah berpindah ke brand pesaing tersebut, apalagi brand tersebut menawarkan pula ongkos kirim yang lebih murah. Selain itu, pelayanan yang lebih baik dari kompetitor menjadi nilai tambah SiCepat bagi konsumen. Salah satu dari dampak membeli produk adalah repurchase atau pembelian kembali (Kristanto \& Firdausy, 2021). Jadi, loyalitas pelanggan tidak hanya berhubungan dengan frekuensi pemakaian dari suatu merek (McCullan \& Gilmore, 2008) tetapi juga faktor lain seperti harga, kualitas, pelayanan, dan lainnya.

Dalam studi sebelumnya, Ren et al. (2015) meneliti faktor yang dapat mempengaruhi customer loyalty yaitu brand image, service quality, dan customer satisfaction. Hasilnya menunjukkan bahwa hanya brand image yang berpengaruh secara positif terhadap customer loyalty, sedangkan, service quality dan customer satisfaction tidak mempengaruhi customer loyalty secara langsung. Tetapi, penelitian lain menemukan bahwa service quality dan customer satisfaction juga mempunyai pengaruh positif terhadap customer loyalty. Misalnya, Rashid et al. (2015) menemukan bahwa service quality dan customer satisfaction berpengaruh positif dan siginifikan terhadap customer loyalty konsumen restoran cepat saji di Malaysia. Kemudian penelitian Santouridis \& Trivellas (2010) juga menemukan service quality dan customer satisfaction berpengaruh positif terhadap customer loyalty.

Service quality merupakan keunggulan perusahaan dalam kualitas layanan dibandingkan dengan kompetitor (Tjiptono, 2005). Keunggulan inilah yang membuat konsumen memilih SiCepat dibandingkan perusahaan lain. Jadi, keunggulan ini dapat menjadi pertimbangan konsumen untuk menggunakan SiCepat dimasa depan. Kelebihan kompetitif ini dapat menjadi daya tarik perusahaan di bidang jasa yang tidak menjual barang fisik. Konsumen akan membandingkan layanan yang diterima dengan harapannya. Kualitas layanan yang buruk dapat menciptakan kekecewaan terhadap konsumen.

Sekarang, banyak perusahaan yang menganggap konsumen tidak loyal pada brand tertentu (Rundle-Thiele, 2005 \& Kapferer, 2005). Hal ini terjadi karena konsumen lebih memilih perusahaan yang dapat menguntungkan dirinya serta tergantung kepada situasi dan kondisi, sehingga konsumen bisa saja memilih lebih dari satu brand. Konsumen yang menggunakan produk dengan merek yang bagus akan memberikan kepuasan (Witama \& Keni, 2020), kemudian akan menciptakan customer loyalty. Brand SiCepat merepresentasikan kecepatan pengirimannya, sehingga mempunyai kesan yang positif. Apabila timbul persepsi negatif, 
misalnya SiCepat tidak dapat menjanjikan pengiriman yang cepat, konsumen bisa saja berpindah ke brand pesaing.

Gaffar (2007) menyebutkan salah satu faktor yang membuat konsumen loyal adalah kepuasan (satisfaction). Hal ini dapat terjadi apabila realita sesuai dengan ekspektasinya. Konsumen dapat dikatakan puas terhadap SiCepat saat sesuatu yang didapatkan sesuai dengan harapannya. Masalah yang umumnya terjadi seperti kualitas pelayanan yang buruk atau ongkos kirim yang lebih mahal tetapi dengan kualitas yang sama dengan merek lain. Hal-hal seperti ini terkadang dapat membuat konsumen merasa tidak puas terhadap suatu merek. Sedangkan, kepuasan pasca-penggunaan merupakan pertimbangan konsumen untuk beralih ke kompetitor atau tidak (Girffin, 2005).

Penelitian ini ditujukan untuk melengkapi penelitian sebelumnya dengan fokus pada faktor yang mempengaruhi customer loyalty pada perusahaan jasa pengiriman barang PT. SiCepat Ekspres Indonesia. Oleh karena itu, judul penelitian ini Pengaruh Brand Image, Service Quality, dan Customer Satisfaction terhadap Customer Loyalty SiCepat di Jabodetabek.

\section{LANDASAN TEORI}

Landasan teori dalam penelitian ini menggunakan teori consumer behavior theory. Lamb et al. (2001) menjelaskan, perilaku konsumen merupakan proses dan pertimbangan agar konsumen dapat memutuskan untuk memakai barang atau jasa. Salah satu model perilaku konsumen yaitu Engel Kollat Blackwell Model (Engel et al., 1978), yang dimulai dari pengenalan masalah, lalu mengumpulkan informasi termasuk pengalaman, kemudian mengevaluasi dan membandingkan dengan merek lain, terakhir hasil yang menunjukkan adanya kepuasan atau tidak dari penggunaan barang atau jasa.

Kemudian, teori lain yang mendukung yaitu Theory of Reasoned Action (Ajzen, 1975), dimana teori ini menjelaskan bahwa perilaku konsumen saat pembelian terjadi secara sadar dan berdasarkan pertimbangan rasional dari informasi yang didapat. Teori ini dikembangkan untuk menjelaskan bagaimana konsumen mengarah pada perilaku pembelian tertentu (Fishbein, 1980). Jadi, di dalam teori ini terdapat hubungan antara perilaku konsumen dan intensi pengunaan suatu produk.

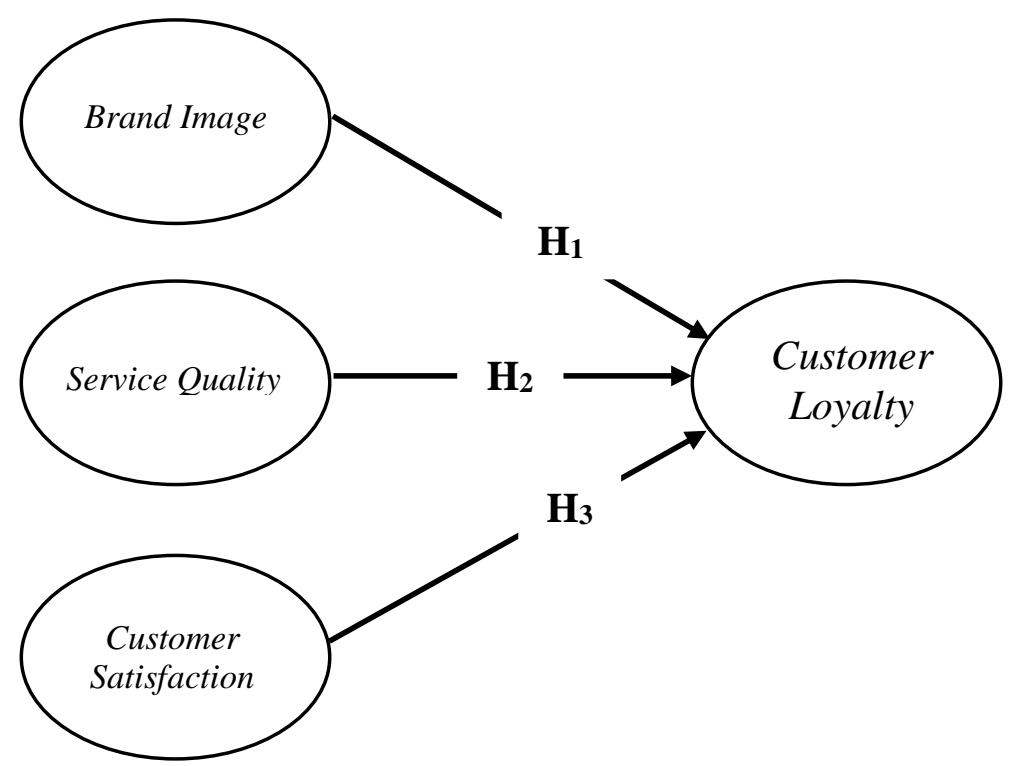

Gambar 2. Kerangka Pemikiran

Hipotesis dalam penelitian ini yaitu sebagai berikut :

$\mathrm{H}_{1}$ : Brand image berpengaruh positif terhadap customer loyalty SiCepat di Jabodetabek 
$\mathrm{H}_{2}$ : Service quality berpengaruh positif terhadap customer loyalty SiCepat di Jabodetabek

$\mathrm{H}_{3}$ : Customer satisfaction berpengaruh positif terhadap customer loyalty SiCepat di Jabodetabek

\section{METODOLOGI}

Desain penelitian menggunakan metode deskriptif. Dalam desain ini, dideskripsikan atau dijelaskan bagaimana pengaruh brand image, service quality, dan customer satisfaction terhadap customer loyalty.

Populasi penelitian ini yakni seluruh pengguna SiCepat di Jabodetabek. Namun, jumlah populasi konsumen SiCepat tidak diperoleh sehingga digunakan pemilihan sampel nonprobability sampling. Teknik pemilihan sampel yang digunakan yakni sampel non-probability sampling khususnya teknik convenience sampling. Sedangkan, teknik pengumpulan data dilakukan dengan cara membagikan kuesioner dengan menggunakan google form secara online. Kuesioner disebarkan menggunakan link melalui media sosial WhatsApp, Facebook, dan Instagram. Hal ini dilakukan karena keterbatasan waktu dan tempat. Kuesioner yang dibagikan melalui WhatsApp dan Facebook akan disertakan link g-form dan fokus dikirimkan kepada group. Kemudian, kuesioner yang dibagikan melalui Instagram akan dikirimkan link kepada beberapa followers secara acak melalui direct/private message.

Responden yang dijadikan sampel adalah mereka yang telah memenuhi kriteria yaitu responden mengetahui perusahaan SiCepat dan pernah atau sedang menggunakan layanan SiCepat. Ukuran sampel yang dikumpulkan sebanyak 100 responden. Jumlah ini karena pengolahan data menggunakan SEM-PLS dengan lisensi student, yang terbatas hanya untuk 100 sampel. Sampel ini diolah menggunakan SEM-PLS versi 3.3.3.

\section{HASIL ANALISIS DATA}

\section{Hasil Analisis Validitas}

Validitas yaitu sejauh mana variabel penelitian dapat mengukur apa yang sedang diteliti (Blumberg et al., 2005). Selain itu validitas digunakan untuk menguji apakah pertanyaan dalam kuesioner dapat memberikan hasil yang valid (Ghoszali, 2009).

Dari hasil analisis AVE menunjukkan bahwa semua variabel yang digunakan valid secara konvergen, karena tiap variabel menunjukkan nilai > 0,5 seperti yang ditunjukkan pada Tabel 1 .

Tabel 1. Average Variance Extracted

\begin{tabular}{|l|c|c|c|}
\hline \multicolumn{1}{|c|}{ Variabel } & Nilai Minimum & $\begin{array}{c}\text { Average Variance Extracted } \\
\text { (AVE) }\end{array}$ & Keterangan \\
\hline Brand Image & 0,5 & 1,000 & Valid \\
\hline Service Quality & 0,5 & 1,000 & Valid \\
\hline Customer Satisfaction & 0,5 & 0,536 & Valid \\
\hline Customer Loyalty & 0,5 & 0,540 & Valid \\
\hline
\end{tabular}

Nilai ideal untuk loading factor yaitu 0,7. Berdasarkan Tabel 2, terdapat tiga hasil yang memiliki nilai dibawah 0,7 maka dianggap tidak valid, selebihnya diatas 0,7 atau valid. Tetapi, teori lain mengatakan selama nilai ini tidak dibawah 0,4 , maka masih dapat dianggap valid. Jadi, keseluruhan nilai pada loading factor dapat dianggap valid secara konvergen karena ketiga nilai tersebut masih diatas 0,5 . 
Tabel 2. Loading Factor

\begin{tabular}{|l|c|c|c|c|}
\hline & Brand Image & Customer Loyalty & $\begin{array}{c}\text { Customer } \\
\text { Satisfaction }\end{array}$ & Service Quality \\
\hline BI4 & 1,000 & & & \\
\hline CL1 & & 0,747 & & \\
\hline CL2 & & 0,697 & & \\
\hline CL3 & 0,743 & & \\
\hline CL5 & 0,752 & & \\
\hline CS1 & & 0,817 & \\
\hline CS2 & & & 0,783 & \\
\hline CS3 & & & 0,658 & \\
\hline CS4 & & & 0,656 & 1,000 \\
\hline SQ4 & & & & \\
\hline
\end{tabular}

Selanjutnya, pada Tabel 3, dari hasil analisis Fornell-Larcker dapat disimpulkan bahwa keseluruhan variabel valid secara diskriminan, karena nilainya lebih besar daripada hubungan antar konstruk/ nilai disampingnya.

\section{Tabel 3. Fornell-Larcker Criterion}

\begin{tabular}{|l|c|c|c|c|}
\hline & Brand Image & $\begin{array}{c}\text { Customer } \\
\text { Loyalty }\end{array}$ & $\begin{array}{c}\text { Customer } \\
\text { Satisfaction }\end{array}$ & Service Quality \\
\hline Brand Image & $\mathbf{1 , 0 0 0}$ & & & \\
\hline Customer Loyalty & 0,391 & $\mathbf{0 , 7 3 5}$ & & \\
\hline Customer Satisfaction & 0,485 & 0,610 & $\mathbf{0 , 7 3 2}$ & \\
\hline Service Quality & 0,266 & 0,511 & 0,462 & $\mathbf{1 , 0 0 0}$ \\
\hline
\end{tabular}

Kemudian, Tabel 4 memperlihatkan nilai tiap indikator lebih besar daripada indikator lainnya. Jadi, tiap variabel dalam penelitian ini telah memenuhi kriteria validitas diskriminan.

Tabel 4. Cross Loadings

\begin{tabular}{|l|c|c|c|c|}
\hline & Brand Image & $\begin{array}{c}\text { Customer } \\
\text { Loyalty }\end{array}$ & $\begin{array}{c}\text { Customer } \\
\text { Satisfaction }\end{array}$ & Service Quality \\
\hline BI4 & 1,000 & 0,391 & 0,485 & 0,266 \\
\hline CL1 & 0,213 & 0,747 & 0,555 & 0,353 \\
\hline CL2 & 0,338 & 0,697 & 0,425 & 0,439 \\
\hline CL3 & 0,297 & 0,743 & 0,417 & 0,278 \\
\hline CL5 & 0,307 & 0,752 & 0,380 & 0,422 \\
\hline CS1 & 0,473 & 0,563 & 0,817 & 0,404 \\
\hline CS2 & 0,403 & 0,437 & 0,783 & 0,346 \\
\hline CS3 & 0,241 & 0,300 & 0,658 & 0,213 \\
\hline CS4 & 0,247 & 0,428 & 0,656 & 0,349 \\
\hline SQ4 & 0,266 & 0,511 & 0,462 & 1,000 \\
\hline
\end{tabular}

Berdasarkan Tabel 1, Tabel 2, Tabel 3, dan Tabel 4, menunjukkan bahwa keseluruhan variabel dalam penelitian ini valid.

\section{Hasil Analisis Reliabilitas}

Reliabilitas merupakan ukuran seberapa konsisten penilaian yang didapat meskipun telah dilakukan uji secara berulang dengan subjek yang sama di waktu yang berbeda (Anastasia \& Urbina, 1998). Dalam SEM, pengukuran reliabilitas menggunakan tiga alat ukur. Cronbach's Alpha dengan nilai $<0,7$, data dapat dikatakan tidak reliabel apabila nilainya $>0,7$. Composite Reliability dengan nilai $<0,7$, data dikatakan tidak reliabel apabila nilainya $>0,7$. 
Pengujian Croanbach's Alpha menunjukkan nilai < 0,7 pada tiap variabel, seperti yang dapat dilihat pada Tabel 5. Jadi, seluruh variabel dalam penelitian ini dapat dikatakan reliabel.

Tabel 5. Croanbach's Alpha

\begin{tabular}{|l|c|c|c|}
\hline \multicolumn{1}{|c|}{ Variabel } & Nilai Minimum & Cronbach's Alpha & Keterangan \\
\hline Brand Image & 0,7 & 1,000 & Reliabel \\
\hline Service Quality & 0,7 & 1,000 & Reliabel \\
\hline Customer Satisfaction & 0,7 & 0,713 & Reliabel \\
\hline Customer Loyalty & 0,7 & 0,717 & Reliabel \\
\hline
\end{tabular}

Kemudian, dari hasil pengujian composite realiability, dapat disimpulkan bahwa semua variabel yang digunakan reliabel, karena tiap variabel menunjukkan nilai $>0,7$ seperti yang disajikan pada Tabel 6.

Tabel 6. Composite Reliability

\begin{tabular}{|l|c|c|c|}
\hline \multicolumn{1}{|c|}{ Variabel } & Nilai Minimum & Composite Reliability & Keterangan \\
\hline Brand Image & 0,7 & 1,000 & Reliabel \\
\hline Service Quality & 0,7 & 1,000 & Reliabel \\
\hline Customer Satisfaction & 0,7 & 0,821 & Reliabel \\
\hline Customer Loyalty & 0,7 & 0,824 & Reliabel \\
\hline
\end{tabular}

\section{Path Coefficient}

Path Coefficient digunakan untuk mengetahui hubungan antar-variabel, dimana mempunyai rentang nilai -1 sampai +1 . Menurut Hair et al. (2014) nilai koefisien mendekati +1 mengindikasikan hubungan yang kuat dan positif sedangkan nilai koefisien mendekati -1 mengindikasikan hubungan yang kuat dan negatif.

Tabel 7. Path Coefficient

\begin{tabular}{|l|c|}
\hline & Path Coefficient \\
\hline Brand image $\rightarrow$ Customer loyalty & 1,270 \\
\hline Service quality $\rightarrow$ Customer loyalty & 3,748 \\
\hline Customer satisfaction $\rightarrow$ Customer loyalty & 4,550 \\
\hline
\end{tabular}

Berdasarkan Tabel 7, Customer satisfaction menjadi prediktor terbesar terhadap customer loyalty dengan nilai 4,550, selanjutnya yaitu service quality, dan yang terendah adalah brand image.

\section{Effect Size (f-square)}

Uji $f$-square digunakan untuk melihat dampak perubahan tiap variabel kepada nilai $\mathrm{R}^{2}$. Menurut Cohen (1988), nilai 0,02 dianggap lemah, 0,15 dianggap cukup/ sedang, dan 0,35 dianggap kuat.

Tabel 8. $f$-Square

\begin{tabular}{|l|c|}
\hline & $f$-Square \\
\hline Brand Image & 0,016 \\
\hline Service Quality & 0,116 \\
\hline Customer Satisfaction & 0,212 \\
\hline
\end{tabular}


Berdasarkan Tabel 8, nilai $f$-square pada brand image mempunyai pengaruh yang lemah terhadap customer loyalty sebesar 0,016, service quality mempunyai hubungan yang cukup terhadap customer loyalty sebesar 0,116 , dan customer satisfaction mempunyai hubungan yang cukup terhadap customer loyalty sebesar 0,212.

\section{Coefficient of determination $(R-$ Square $)$}

Uji $R$ - Square digunakan untuk mengukur seberapa besar variabel independen menjelaskan variabel dependen, yaitu brand image, service quality, dan customer satisfaction untuk menjelaskan customer loyalty.

Tabel 9. R-Square

\begin{tabular}{|l|c|}
\hline & $R$ - Square \\
\hline Customer Loyalty & 0,448 \\
\hline
\end{tabular}

Tabel 9 memperlihatkan nilai $R$-Square sebesar 0,448, maka model penelitian ini dapat dianggap cukup baik (moderat) karena memiliki nilai lebih dari 0,33 (Chin, 1998). Artinya variabel customer loyalty dapat menjelaskan sebesar 44,8\% dari ketiga variabel yaitu brand image, service quality, dan customer satisfaction, dan sebesar 55,2\% dijelaskan variabel lainnya selain ketiga variabel tersebut.

\section{Predictive Relevance $(Q-$ Square $)$}

Uji $Q$ - square digunakan untuk melihat kemampuan untuk memprediksi model variabel. Nilai $Q$-square lebih dari 0 dianggap model mempunyai prediksi relevansi, apabila nilainya kurang dari 0 , maka model tidak memiliki prediksi relevansi.

Tabel 10. Q-Square

\begin{tabular}{|l|c|}
\hline & $Q$ - Square \\
\hline Customer Loyalty & 0,211 \\
\hline
\end{tabular}

Tabel 10 menunjukkan nilai $Q$-Square yang didapat sebesar 0,211, maka model penelitian ini memiliki prediksi relevansi yang cukup baik, karena mempunyai nilai lebih besar dari $0(<$ $0)$ dan lebih besar dari $0,15(<0,15)$.

\section{Goodness of Fit (GoF)}

Goodness of Fit digunakan untuk mengukur seberapa besar pengaruh antar variabel, dengan pembagian nilai 0,10 yaitu kecil, 0,25 yaitu cukup, dan 0,36 yaitu besar.

$$
\text { Rumus untuk mencari } \mathbf{G o F} \Rightarrow \sqrt{ }_{\text {Average }} \mathrm{AVE} \times \mathrm{R}^{2}
$$

$$
1,000+1,000+0,536+0,540 / 4 \times 0,448=\mathbf{0 , 5 8 6}
$$

Dari hasil tersebut, dapat dikatakan tiap variabel mempunyai hubungan yang kuat, karena mempunyai nilai lebih besar dari 0,36 .

\section{Hasil Pengujian Hipotesis}

Dari pengujian path coefficient (Tabel 11), hasilnya menunjukkan brand image berpengaruh positif tetapi tidak signifikan terhadap customer loyalty, yang bertentangan dengan penelitian Ren et al. (2015), sedangkan customer satisfaction dan service quality berpengaruh positif dan signifikan terhadap customer loyalty, dimana sejalan dengan penelitian Santouridis \& Trivellas (2010). 
Tabel 11. Hasil Path Coefficient

\begin{tabular}{|l|c|c|c|c|}
\hline & Path Coefficient & $\boldsymbol{t}$ - statistics & $\boldsymbol{p}$ - values & Hasil \\
\hline $\begin{array}{l}\text { Brand Image } \\
\text { Customer Loyalty }\end{array}$ & 1,270 & 1,256 & 0,210 & $\begin{array}{l}\text { Berpengaruh Positif \& } \\
\text { Tidak Signifikan }\end{array}$ \\
\hline $\begin{array}{l}\text { Service Quality } \rightarrow \\
\text { Customer Loyalty }\end{array}$ & 3,748 & 4,329 & 0,000 & $\begin{array}{c}\text { Berpengaruh Positif \& } \\
\text { Signifikan }\end{array}$ \\
\hline $\begin{array}{l}\text { Customer } \\
\text { Satisfaction } \\
\text { Customer Loyalty }\end{array}$ & 4,550 & 3,343 & 0,001 & $\begin{array}{l}\text { Berpengaruh Positif \& } \\
\text { Signifikan }\end{array}$ \\
\hline
\end{tabular}

\section{PEMBAHASAN}

Berdasarkan penelitian yang dilakukan, terdapat 100 responden yang berpartisipasi dan merupakan orang yang pernah atau sedang menggunakan layanan ekspedisi SiCepat. Mayoritas responden merupakan laki-laki dan sisanya adalah wanita, dengan usia 21-30 tahun dan masih berstatus pelajar/ mahasiswa, dimana dalam sebulan mereka juga cukup sering berbelanja online. Hal ini membuktikan banyak dari pengguna SiCepat merupakan generasi milenial yang menyukai berbelanja online. Pendidikan terakhir responden yaitu SMA dan S1, jadi dianggap mereka dapat memahami dan mengisi pertanyaan kuesioner dengan baik. Wilayah domisili responden terbanyak berasal dari Depok. Terakhir, alasan mengapa mereka memilih SiCepat dibandingkan perusahaan lain yaitu kebanyakan memilih karena pengaruh dari lingkungan sekitar, hal ini berarti word-of-mouth merupakan jenis pemasaran yang berpengaruh terhadap keputusan konsumen untuk menggunaan layanan SiCepat.

Pada objek penelitian variabel terdapat beberapa indikator yang dikeluarkan karena nilai yang tidak memenuhi 0,5, sehingga menyebabkan AVE dan Cronbach's alpha rendah. Dalam variabel brand image terdapat empat indikator yang di keluarkan yaitu "Fitur pada layanan SiCepat bagus", "Citra positif memikat saya untuk memilih layanan SiCepat", "Layanan tambahan meningkatkan kepuasan", dan "Staff SiCepat bersahabat".

Tujuh indikator yang dikeluarkan dalam variabel service quality yaitu, "SiCepat memberikan pelayanan yang tepat dengan waktu yang tepat juga, sesuai dengan komitmen", "Layanan SiCepat terpercaya", "Staff SiCepat selalu tersedia melayani saya saat mendapat kendala", "SiCepat mengerti bagaimana cara memperhatikan kebutuhan layanan ekspedisi saya", "Jam kerja SiCepat memudahkan untuk melayani kebutuhan saya", "SiCepat mempunyai mesin dan perlatan yang modern dan canggih", dan "Kantor cabang SiCepat banyak, menciptakan kepercayaan untuk saya".

Kemudian, satu indikator yang dikeluarkan pada customer satisfaction yaitu "Tarif ongkos pengiriman murah". Terakhir, terdapat satu indikator yang juga dihapus pada customer loyalty yaitu "Saya menikmati menjadi pelanggan SiCepat"

Analisa validitas dan reliabilitas menunjukkan hasil yang valid dan reliabel, tetapi pada outer loading terdapat tiga hasil yang bernilai dibawah 0,7 untuk pengukuran ideal, tetapi pada beberapa teori, apabila nilainya masih lebih dari 0,5 , maka masih dapat diterima, tetapi nilai indikator pada outer loading harus dihilangkan apabila nilainya sangat rendah atau kurang dari 0,40 (Hair et al., 2011). Jadi, keseluruhan nilai pada outer loading masih dapat diterima karena bernilai lebih dari 0,5 .

Kemudian, pengujian pada path coefficient untuk mengetahui hubungan antar variabel, hasilnya customer satisfaction memiliki hubungan terbesar terhadap customer loyalty dengan nilai 4,550, diikuti service quality dengan nilai 3,748, dan brand image dengan nilai terendah yaitu 1,270 . Hasil $R$-square menunjukkan bahwa variabel customer loyalty dapat menjelaskan 
variabel brand image, service quality, dan customer satisfaction dengan cukup baik yaitu sebesar 44,8\%. Hasil $Q$-square menunjukkan customer loyalty dapat memprediksi model dengan cukup baik. Terakhir, pengujian Goodness of Fit bernilai 0,586 yang mengindikasikan tiap variabel mempunyai hubungan yang kuat.

Berdasarkan pengujian hipotesis pertama $\left(\mathrm{H}_{1}\right)$ menunjukkan bahwa brand image berpengaruh positif tetapi tidak signifikan terhadap customer loyalty, meskipun banyak penelitian menunjukkan bahwa keduanya mempunyai pengaruh yang positif dan signifikan, contohnya peneltian Ren et al. (2015) dan Durmaz et al. (2018). Hal ini mungkin dapat terjadi karena masyarakat yang kurang mengenal merek SiCepat dibandingkan pesaing lainnya seperti JNE, J\&T, dan Pos Indonesia. Seperti yang dikatakan Rundle-Thiele (2005) \& Kapferer (2005), dimana jaman sekarang banyak perusahaan yang menganggap apabila konsumen tidak loyal pada brand tertentu, karena konsumen bisa saja ingin menggunakan jasa pengiriman yang paling murah. Tiap jasa ekspedisi melakukan kegiatan yang sama, yaitu mengirimkan barang ke konsumen dan yang membedakannya hanya jenis layanan yang ditawarkan. Selain itu, beberapa kompetitor menawarkan ongkos kirim yang lebih murah seperti Wahana dan JNE (tergantung wilayah pengiriman), kemudian hanya sedikit konsumen yang memanfaatkan teknologi dari SiCepat dapat menjadi penyebab brand image yang kurang baik. Maka, hipotesis penelitian ini ditolak.

Selanjutnya, pengujian hipotesis kedua $\left(\mathrm{H}_{2}\right)$ menunjukkan bahwa, service quality dapat mempengaruhi secara positif dan signifikan customer loyalty. Sesuai dengan penelitian sebelumnya yaitu Santouridis \& Trivellas (2010) yang menyatakan service quality berpengaruh positif terhadap customer loyalty pengguna telepon di Yunani. Kemudian, penelitian Rashid et al. (2015) yang menemukan bahwa service quality berpengaruh positif dan siginifikan terhadap customer loyalty pada restoran cepat saji di Malaysia. Jadi, service quality pada SiCepat masih memegang peranan penting dalam mempertahankan customer loyalty. Dengan memberikan kualitas layanan yang lebih unggul dari pesaing, dapat membuat persepsi yang positif dari konsumen terhadap SiCepat. Maka, hipotesis penelitian ini diterima.

Terakhir, pengujian hipotesis ketiga $\left(\mathrm{H}_{3}\right)$ menunjukkan bahwa customer satisfaction memberikan pengaruh positif dan signifikan terhadap customer loyalty. Hal ini sesuai dengan penelitian sebelumnya yaitu Sabir et al. (2013) yang menyatakan bahwa customer satisfaction mempunyai hubungan yang positif dan signifikan terhadap customer loyalty pengguna telepon di Yunani. Kemudian, penelitian Özkan et al. (2020) yang membuktikan bahwa customer satisfaction mempengaruhi customer loyalty bank di Turkey. Jadi, customer satisfaction juga memberikan pengaruh positif terhadap customer loyalty jasa ekspedisi. Semakin puas konsumen SiCepat, akan kecil kemungkinannya berpindah ke brand pesaing. Maka, hipotesis penelitian ini diterima.

Dari ketiga variabel penelitian, customer satisfaction memiliki pengaruh paling kuat terhadap customer loyalty, yaitu sebesar 0,426 berdasarkan hasil loading factor. Hal ini membuktikan bahwa kekuatan terbesar SiCepat dalam menciptakan customer loyalty berasal dari banyaknya konsumen yang puas karena memakai jasa ekspedisi ini.

\section{KESIMPULAN}

Berdasarkan penelitian yang telah dilakukan mengenai brand image, customer satisfaction, dan service quality terhadap customer loyalty SiCepat di Jabodetabek, maka kesimpulan dari penelitian ini sebagai berikut :

1. Brand image berpengaruh positif tetapi tidak signifikan terhadap customer loyalty SiCepat di Jabodetabek 
2. Customer satisfaction berpengaruh positif dan signifikan terhadap customer loyalty SiCepat di Jabodetabek

3. Service quality berpengaruh positif dan signifikan terhadap customer loyalty SiCepat di Jabodetabek

Oleh karena itu, perusahaan SiCepat perlu terus meningkatkan brand image agar masyarakat mengetahui tentang brand perusahaan, sehingga konsumen mempunyai kesan positif untuk mau menggunakan jasa ekspedisi SiCepat. Salah satu caranya dengan komitmen menjaga kepercayaan konsumen yang memakai layanan SiCepat. Kemudian, perusahaan juga harus terus meningkatkan service quality pada layanannya dengan cara memberikan rasa aman sehingga konsumen tidak perlu merasa khawatir, kualitas layanan yang baik membuat konsumen tetap menggunakan SiCepat. Terakhir, customer satisfaction menjadi indikator paling kuat dan penting untuk mendapatkan loyalitas dari pengguna SiCepat, karena banyak dari mereka merasa puas terhadap performanya, maka perusahaan disarankan untuk terus meningkatkan performanya demi menjaga kepuasan para konsumennya.

\section{DAFTAR PUSTAKA}

Ajzen, I. \& Fishbein, M. (1980). Understanding attitudes and predicting social behavior. Englewood Cliffs, NJ: Prentice Hall.

Akbar, M. M. \& Parvez, N. (2009). Impact of Service Quality, Trust, And Customer Satisfaction On Customer Loyalty. ABAC Journal, 29(1), 24-38.

Durmaz, Y. et al. (2018). The Effect of Brand Image and Brand Benefit on Customer Loyalty: The Case of Turkey. International Journal of Academic Research in Business and Social Sciences, 8(5), 528-540.

Fitri, A. N. (2020, October 20). Survei: Di masa pandemi, 85,2\% masyarakat gunakan jasa kurir untuk pengiriman barang. Retrieved March, 2021 from industry.kontan.co.id: https://industri.kontan.co.id/news/survei-di-masa-pandemi-852-masyarakat-gunakanjasa-kurir-untuk-pengiriman-barang

Gaffar, V. (2007). Manajemen Bisnis. Bandung: Alfabeta.

Griffin, J. (2005). Customer Loyalty: How to Earn It How To Keep It. Completely Revised \& Updated.

Ha, C. L. (1988). The theory of reasoned action applied to brand loyalty. Journal of Product and Brand Management, 7(1), 51-61.

Huma, S. et al. (2020). The effect of logistics service quality on customer loyalty: case of logistics service industry. South Asian Journal of Business Studies, 9(1), 43-61.

Kun, H. L. (2012). The Casual Effects of Service Quality, Brand Image, Customer Satisfaction on Customer Loyalty in the Leisure Resort Enterprise, China-USA Business Review, 11(5), 631-642.

Kristanto, H., \& Firdausy, C. M. (2021). Pengaruh Perceived Ease Of Use, Perceived Usefulness, Attitude Toward Using Dan Sales Promotion Terhadap Repurchase Intention Tiket Bioskop Pengguna Aplikasi TIX-ID. Jurnal Manajemen Bisnis Dan Kewirausahaan, 5(3), 226-231.

Leninkumar, V. (2017). The Relationship between Customer Satisfaction and Customer Trust on Customer Loyalty. International Journal of Academic Research in Business and Social Sciences, 7(4), 450-465.

Mai, S., \& Cuong, T. (2021). Relationships between Service Quality, Brand Image, Customer Satisfaction, and Customer Loyalty. Journal of Asian Finance, Economics and Business, 8(3), 585-593.

Ogba, I. E., \& Zhenzhen T. (2009). Exploring the impact of brand image on customer loyalty and commitment in China. Journal of Technology Management in China, 4(2), 132-144. 
Rashid, I. M. A., Yusuf, B. N. M., \& Rani, M. J. A. (2015). The Impact of Service Quality and Customer Satisfaction on Customer Loyalty: Evidence from Fash Food Restaurant of Malaysia. International Journal of Information, Business and Management, 7(4), 201-236.

Ren, F. C., Tai, C. W., I, S., \& Wei, T. Y. (2015). The Influence of Service Quality, Brand Image, and Customer Satisfaction on Customer Loyalty for Private Karaoke Roomsin Taiwan. The Journal of Global Business Management, 11(1), 59-67.

Rundle-Thiele, S., \& Bennett, R. (2001). A brand for all seasons? A discussion of brand loyalty approaches and their applicability for different markets. Journal of Product \& Brand Management, 10(1), 25-37.

Santouridis, I. \& Panagiotis T. (2010). Investigating the impact of service quality and customer satisfaction on customer loyalty in mobile telephony in Greece. The TQM Journal, 22(3), 330-343.

Witama, A. \& Keni K. (2020). The Impact of Brand Image, Perceived Price and Service Quality Toward Customer Satisfaction. Advances in Social Science, Education and Humanities Research, 439, 316-320. 